\title{
Employment of the Quality Function Deployment (QFD) Method in the Development of Food Products
}

\author{
Caroline Liboreiro Paiva and Ana Luisa Daibert Pinto \\ University Federal of Minas Gerais \\ Brazil
}

\section{Introduction}

Currently, in a more intensive way, companies have been forced to adapt to the new competitive market. The technological industry changes' occurring since the 80 's brought implications for the international competition, specially the demarcation of new areas of global competition. That happens due to the acceleration of technological changes added by the shortening of the life cycle of products and processes, besides the increasing of the products differentiation. In fact, what is observed is that these factors have not only led companies to restructure their production systems and their types of management, but above all, to guarantee the capacity to deliver to a market, products even more sophisticated. The ability to realize alternatives to compete in the market, to develop strategies and to invest in appropriate training that is what has ensured the survival and profitability of organizations in this new structure.

In terms of food industry competition, what is observed is that the integrity of the product has become the main focus. This means that product excellence, in the food industry, goes beyond simply offering goods with basic attributes. These attributes have only become a precondition for the company to keep playing the competitive game. In fact, nowadays, the products must not only satisfy, but above all, surprise their customers. What is realized is that these consumers have accumulated experience with several products and become sensitive to small differences in many ways. This means that innovations in products and processes increase the excellence standard of product, making the process of development an essential factor for the competition of enterprises.

Certainly, the best projects require staff competence, efficiency in the work, on the exchange of information between functions and on the understanding of the market needs into technical language. They also require efficiency in problem solving and in the use of its resources. In this sense the Quality Function Deployment (QFD) method has proven to be efficient in order to translate in a more effectively way the needs and expectations of consumers, to promote greater interaction between the teams involved in the project, to accelerate the solution of problems and to reduce the development time.

The QFD was invented in the late 1960's in Japan. Within the context of TQC (Total Quality Control), the Japanese model of quality management system was responsible to cause a revolution in the production system of that country. All that was possible, due to the 
emphasis on the product quality considering the point of view of the customer. QFD is the unfolding, step by step, of functions or operations that make up the product quality. The methodology seeks to solve the problems inherent to the product's development process in their early stages, in a way that the critical points that determine the quality of the product and the manufacturing process are established in the phase of their design and controlled during the development stages. The methodology also ensures the achievement of quality because it works with a focus on consumer needs. More specifically, it translates the consumer's requirements into technical language and then ensures their satisfaction along the process of product's development.

The quality matrix is the tool used to organize the consumer's needs into technical information. The matrix goal is to define the pattern, quantitative or qualitative, of each attribute of quality of the final product. The other matrices are due to the quality matrix and aim to detail the project so that all the factors that contribute to the achievement of the final product are designed, as characteristics of the intermediates products, parameters of the manufacturing process, raw materials and inputs.

In addition, the QFD method assists the management of product development process because it coordinates the flow of information and organizes activities in terms of functions. It promotes the functional integration and rapid resolution of problems.

With all that, the purpose of this chapter is to describe the potential use of the QFD method into product development in food companies. The study initially intends to contextualize the management of product development in the food industry and show the QFD method as a tool capable of directing, in a practice way, how to plan and conduct the activities of the process of product development. So the steps for the application of QFD in the development of a food product will be detailed. In addition, support tools within the marketing research and sensory analysis will be suggested.

\section{Product differentiation: A strategy adopted by the food industry}

The food industry never has launched so many new products as it has in recent years. Due to factors such as technological development, increasing of competitiveness in the sector due to the growth of the competition such in and out of the countries, and greater consumer demand which incorporated new values to its preferences, the shelves of supermarkets receive daily new products (Athayde, 1999).

The focus on markets niche is one of the strongest trends today in the food sector. There is a search for products that provide pleasure to be consumed, such as the sophisticated products with high added value, or looking for fun products aimed at children. Likewise, products that refer to a particular region of the world, or of exotic flavors are searched by another portion of the market of processed foods.

Allied to all that, a strong feature of the new releases is the convenience in food consumption. This requirement is related to changes on consumers' lifestyle. The growing participation of women in the labor market, added by the increasing mobility of consumers, reduced the demand for ingredients to prepare meals at home and increased the offer of practical foods that can be consumed at any time, and of ready to go foods or pre-prepared. Industry has also been required to apply new technologies in the development of food and beverages, specially the search for new ingredients. The changes in consumption habits it is driven by the concern for the health, aesthetics and environment. It demands food products of low-calorie, healthier and natural and environmentally friendly. A strong trend is the 
launch of products, which besides the presence of the sensory and nutritional quality, also present health benefits, so-called functional foods.

It is also important to emphasize the growing importance of equipment suppliers. Companies specializing in process engineering, who believe the research as a basis for technological innovation, have an important role in the development of food products (Earle, 1997). New technologies are able to provide new concepts of product, new alternatives for use, and being difficult to be imitated by competitors.

Finally, in addition to the significant number of new products available on the market in recent years, it is worth noting the great contribution of the sector of packaging for the food market, making it possible that these strategies of differentiation, segmentation and consumer convenience can be realized.

\section{Stages of product development process}

The process of product development, outlined in a model, consists of a sequence of activities ordered in time or a set of tasks that aim to facilitate the management of the process as a whole.

There isn't a standard development model that fits all circumstances and conditions experienced in a company. However, if the company adapts your way of management to a model more suited to its environment, probably the company will get better performance in their innovation processes. Anyway, the consensus is that development must be conducted so that the product reaches the market as quickly as possible, providing to the product the quality expected by customers and having costs optimized.

Students of product development management have different ways of representing the necessary steps to this process. Picture 1 seeks to represent the basic steps; steps that will assist the planning, the development of the product itself and the release of the same. Of course the product will have a greater chance of market success with this process if there is efficient management. For Clark \& Wheelwright (1993), this means that the company should have skills to quickly identify opportunities, which often leads them to introduce new products ahead of their competitors. The best projects require also the team's competence, work efficiency, the exchange of information between functions and translation of the markets needs in technical language. They also required efficiency in problem solving and in the use of resources.

In Picture 1, the process of product development is represented by stage-gates. The stages are the various stages of development and the gates, decision points that precede each stage, opening or closing the door to continue the project (Cooper, 2001). These gates serve as critical steps for assessing the projects. The results of these evaluations are reflected in the decision to continue the project, drop it, stop it or resume it on another occasion.

Before joining the project into the development phase, the organization must seek the means that will ensure that the product will reach customers needs. Several market research research of needs and desires of the consumers, competitive analysis and concept testing will help to define more precisely the concept of the product. The first step in this direction is to translate the information inside and outside of the company in technical language, until you define the product's concept. For this, extract the data through market research, group discussions, customer complaints and tacit knowledge of employees. The various functions involved in the process are then in charge of mapping information and developing the work. 


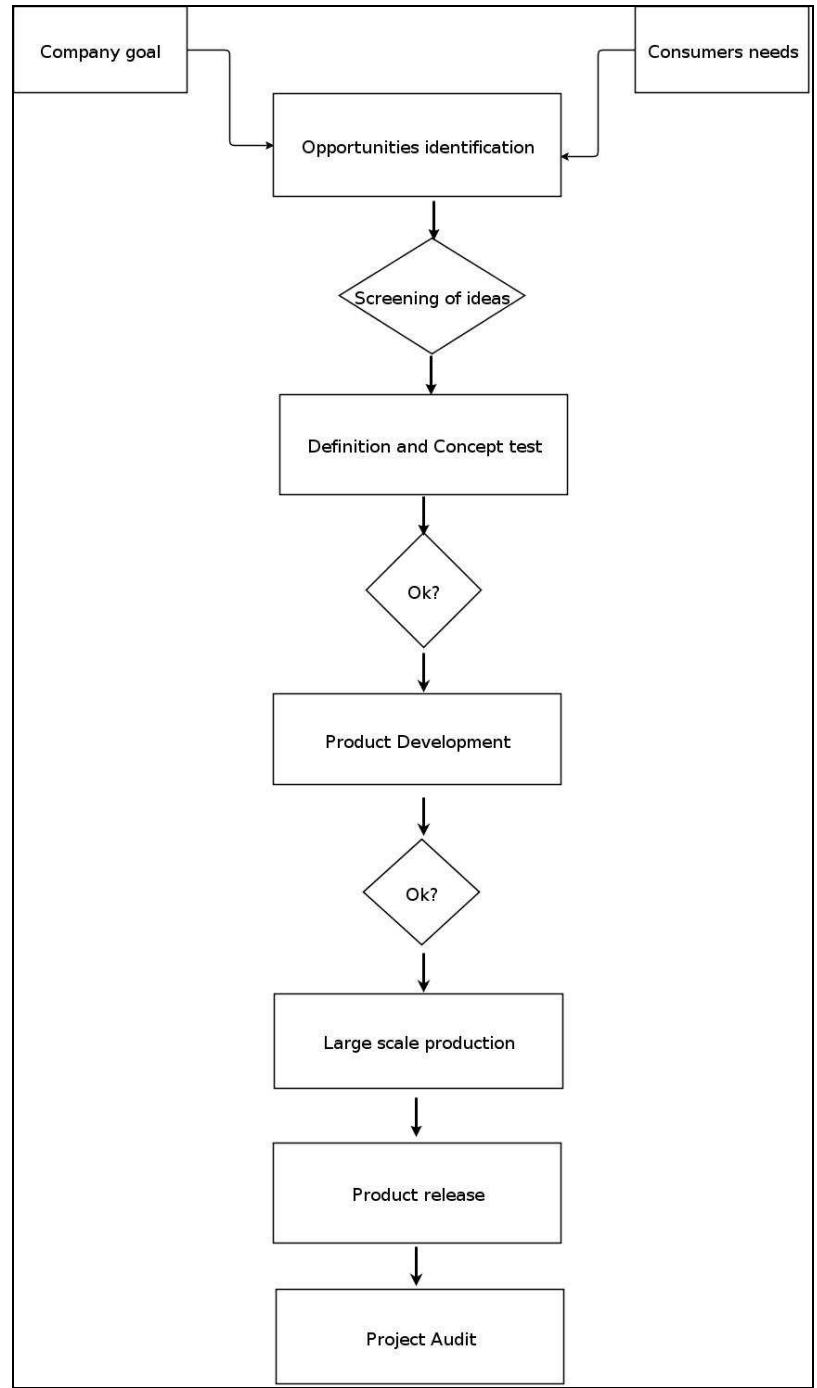

Fig. 1. Stages of the process of product development

In the stage of identifying opportunities, the company must seek ways to generate ideas for the new products. This can be achieved by internal efforts, through research in the departments of $R \& D$, through contests to stimulate ideas for new products, or through the Customer Services, in meetings, using brainstorming techniques, or by stimulating a business culture that valorize the opinions and ideas of employees. On the other hand, the ideas for new products can come from external sources such as quantitative or qualitative research with target consumers. Other sources of ideas can come from university research publications or specialized organs, experience and knowledge of sales staff, contact with suppliers and also reverse lookup on products of competitors. 
In this step it should be also made a prior assessment of the market for each idea, considering its size, segments and potential. It should also be evaluated the feasibility of manufacturing the product, the ability to be accepted by the market as well as their vulnerability towards competitors products or substitutes.

The ideas should then go through a team that will evaluate and select the ideas by checking out promising, profitable or those that must be rejected. Every idea that is nominated as possible to be developed will then go to the stage of definition and testing of its concept. The concept of a product can be defined as the expected benefits to meet the needs and expectations of consumers. The concept definition phase must determine the target audience, what are the main benefits that the product will present and a more appropriate occasion to consume it.

After the definition of the product's conception is convenient to test it. The test of the concept is a marketing research technique used to assess the market potential of the concept. Provides estimates of intent to purchase and sales volume. Define "who" would use the product, in which "circumstances" and how "often".

Finally, we must make the financial analysis of the project. The size of the market, the expected market share, the price analysis, along with technical cost estimates of equipment and for product launch are the inputs needed to make such an analysis. Once the project is defined, the only thing needed is that top management approves it, so the development of the product can be started.

Only then the product will go into the product development stage itself. However, it is necessary to first make the process and product planning. Regarding the product is necessary to define the product requirements, such as: the ingredients that will be needed, the most suitable additives, the quantity/volume that will be marketed. It is still important to define the requirements of legislation, such as: what will be the standard of identity and quality of the product, if the planned additives are allowed by the competent organizations and what the limit of application, and also the labeling requirements.

In relation to the manufacture of the product, it is necessary to first specify the parameters of the process, which involves the study of manufactured technology and the parameters of quality and of process that need to be controlled in the manufacturing line.

The development process then proceeds to the phase of preparation of the prototypes, usually in an industrial kitchen for the definition of the formulation and of the sensory products parameters. Soon after it should be performed sensory tests in one or more prototypes, if possible with a sample of the target market, in order to verify the acceptance of the product.

Thus, the development of the product passes to the manufacturing phase of the pilot which consists in the manufacture of the product on a small industry scale, in order to define the quality parameters of intermediate products and process parameters that will be monitorized. Likewise, tests should be made of pilot products: sensory tests, again if possible with a sample of the target market, in order to verify if the product remains viable. Only then the company will plan the production on an industrial scale.

Soon afterwards the company can produce on an industrial scale, to launch the new product. In the launch phase is necessary to determine: a release date, geographical location and potential consumers in the target market. It is necessary to establish an advertising plan, that would include promotional and dissemination strategies. 
Finally, the last step is to evaluate the project developed. The company has an opportunity to implement its system of product development through learning gained during the implementation of each individual project. The project audit aims to verify the strong and weak points and to define strategies for improving the performance of future projects. It is believed that only a deep understanding of the causes of problems and circumstances in which they occur, will allow the company to improve the performance of development activities, by improving the procedures, processes, management skills, methods, making the company able to develop a faster process, more efficient in the use of resources and in the development of products of higher quality.

\section{The QFD Method}

The QFD Method, Quality Function Deployment, originated in Japan in the late 60's, as a result of the study of the professors Akao and Mizuno (Mizuno, 1969). On this occasion, the movement for the Total Quality in that country had already achieved very significant results. The ideas of quality emerged after World War II starting with the Statistical Process Control (SPC) and evolved in the late 60's, to a much broader approach, in which it was already understood at the system level, and not only in technical terms or isolated functions, but also in management terms, and thus practiced throughout the whole organization. To get an idea, in 1968, the Quality Control (QC) in Japan had already reached the point where virtually all firms made usage of the QC in some way (Mizuno, 1969).

However, there was a gap in establishing the quality into a level of development of products. There were questions about what points should be considered in the design phase of projects that could operationalize the quality planning of both products and processes. There were also difficulties in ensuring that the planned quality was actually executed in the phase of serial production (Mizuno, 1969).

Then arises from these needs, the initial concepts of Quality Deployment, and in 1972, after conducting some researches, the ideas become practically implemented. In 1978, it was published the book "Quality Function Deployment" which gave a new impetus to the dissemination of QFD, causing it to be quickly implemented in several companies in the country.

Currently, QFD inspires a strong interest in the world, generating ever-new applications, practitioners and researchers each year. This method is in use in several countries in the world such as South Africa, Germany, Australia, Brazil, China, Spain, United States, Italy, India, Japan, Mexico, United Kingdom, Sweden and others, not only in product development, but also in developing manufacturing processes, software, services, etc. (Akao \& Mazur, 2003; Chan \& Wu, 2002).

In the U.S., QFD has become known in 1983 after conducting a seminar on the subject in Chicago. It was initially introduced in the 3M Corporation. Currently, the use of QFD in the U.S. is in almost all industry sectors, particularly in the automotive, electronics, software and services industry. It is also used by the space industry.

In 1996 a survey was conducted through a collaboration of Tamagawa University and the University of Michigan on the applications of QFD in the U.S. and Japan. It was selected 400 companies from each country. 146 Japanese companies (37\%) and 147 American (37.6\%) responded to the survey. According to the results, 31.5\% of Japanese companies and $68.5 \%$ of Americans use the QFD (Akao \& Mazur, 2003). 
In Europe, QFD is also well known and many application cases have been reported. In other parts of the world, one can mention the innovative applications of QFD in Australia in the area of strategic planning and development of new business or improving existing business (Melo Filho \& Cheng, 2007).

In emerging countries such as Brazil, QFD was introduced in 1989 and the concern now is how to make the method more effective, better understood and applied (Akao \& Ohfuji, 1989). In China, the Quality Bureau from the State Bureau of Technical Supervision, a national agency of The People's Republic of China, has invited Professor Akao to give QFD seminars in Peking and Shanghai since 1994. India has shown a strong interest in the application of QFD, specially in software industry and in manufacturing industries such as trucks, automobiles, and farm tractors (Akao \& Mazur, 2003).

The true in general is that the QFD method has ensured the achievement of project quality because it relays in one point that is the most cited by scholars of the subject as essential to the success of the product: a focus on customer needs. In addition, assists in managing the development process because it coordinates the flow of information and organizes activities in a function level. Thus promoting cross-functional integration and quick problem solving.

\subsection{Method's approach}

The QFD method, as it was originally designed by the professors Akao and Mizuno, includes the deployment of information, called the Quality Deployment (QD) and displays of work, addressed as Quality Function Deployment narrowly defined or restricted (QFDr). In the first approach, QFD works detailing the necessary information to the innovation process. For that, are used tables, matrices, and the conceptual model, called the basic units of the QD. On the tables the data are organized, which in turn will be linked into the matrices. The interaction between the matrices is shown in the conceptual model (Akao, 1996).

The beginning of the process of extracting information in the QFD always starts from a table, so it is considered as the elementary unit of the method. It has the main purpose of deploying the information, always starting from a more general level to a more concrete. Using data from market research or internal information of the company, the work team uses the tables to detail the information, which are then arranged so that they are grouped according to their level of abstraction. Thus, the characteristics, requirements or functions that aren't so explicit, they become more clear for the working group.

The use of matrices in QFD aims to translate succinctly the relationship between two tables. It is a way of storing information and at the same time, to visualize the degree of interaction between each element of a table in relation to all the other elements of the other.

The conceptual model is the structure within the QFD that allows the visualization of the path taken to deploy the information until they get the technical standard processes. According to the sequence of matrices, it is able to verify a relation of cause and effect between the characteristics of the final product, its components, their functions, costs, raw materials and intermediate processes for their manufacture. Thus, it has been stored in a visible and detailed way, all product design and process.

The second approach of the method refers to the deployment of the work (QFDr). The technical and management procedures are established to ensure that all functions involved in the activities have their tasks previously established. The QFDr aims to specify who will do the job and how it will be done. Thus, from this deployment of the work it can be 
generated a set of documents, such flowchart of product development and a plan to manage the product development activities. The first determines the functional areas involved in each stage of development and the procedures for carrying out the work. The second specifies the schedule for each activity within the project.

\subsection{Elaboration of the quality matrix of the final product}

The Quality Matrix of the finished product is the first matrix that should be developed within the QFD method. In it are contained all information relating to the finished product. This topic displays an example of developing step-by-step from the quality matrix of a functional ready to bake dough for pies (Pinto \& Paiva, 2010). While the development of other matrices of raw materials, intermediate products and processes are not treated in this chapter, the understanding of this first matrix will benefit the reader to understand how the matrices are made in the context of QFD.

\subsubsection{Listing of primitive data}

The primitive data are informations written in colloquial language, which can be collected through interviews or questionnaires with consumers, through discussion with focus groups or can be extracted from consumer complaints. They may also be got from opinions of company employees and in the news world. When the consumer does not directly express their needs, the imagination of scenes, or occasions of consumption, facilitates the description of the item required.

To meet the needs of the target market related to the dough for pies, there was a market research through semi-structured interviews with a sample of thirty possible consumers of the product. In the interview it was assessed the characteristics that the interviewers hoped to find in the ready dough for pies through the deployment of the scene in the manner, place and circumstances under which they would like to consume the product.

With the primitive information obtained, it was listed the greatest possible number of consumer desires. An example of this conversion is when an interviewee said that "the dough for pie should be used for both pies - sweet and salty," and the translation of primitive data for a required item was that "the dough for pie has to have a neutral flavor."

\subsubsection{Establishment of the required qualities}

At this stage you just have to format the primitive language, obtained from the market or from the deployment of scenes, observing certain rules. It is important that the terms of the customer requirements are simple, summarized in a single sentence, without explanation and did not have double meaning, making sure that the desired quality is clear. Whenever possible, you should be careful to avoid expressions in the form of denial, employing for this, affirmatives expressions.

Then the customer requirement qualities must be arranged in a table, the table of required qualities. This table is assembled from right to left. From the more concreted level to the more abstract. Generally, for food products, the markets requirements are grouped in terms of looks or appearance, flavor, texture, ease of preparation.

For the elaboration of the table it should be observe the following script: sentences with the same content should be eliminated to avoid repetition. The sentences should be arranged so that they can be viewed in only one frame (tertiary level, Table 1). It must then be joined in 
groups of four or five sentences with similar content and add expressions of customer requirements that represents the groups formed (secondary level, Table 1). With the phrases of similar content from the previous procedure must be formed other groups and add expressions of customer requirements to represent the groups formed (primary level, Table 1).

\begin{tabular}{|c|c|c|}
\hline Primary Level & Secondary Level & Tertiary Level \\
\hline \multirow{6}{*}{ Looks nice } & \multirow{3}{*}{ Nice texture } & Being soft \\
\hline & & Being crunchy \\
\hline & & $\begin{array}{l}\text { Being a dough that dissolves easily in the } \\
\text { mouth }\end{array}$ \\
\hline & Nice color & Have a color next to cream/beige \\
\hline & \multirow{2}{*}{ Appealing aspect } & Have an uniform size \\
\hline & & Have an uniform thickness \\
\hline \multirow{2}{*}{ Being tasty } & Pleasant aroma & Have an appetizing aroma \\
\hline & Pleasant flavor & Have a neutral taste \\
\hline $\begin{array}{c}\text { Satisfaction of the } \\
\text { preparation }\end{array}$ & Being fully & Being fully \\
\hline Being safe & Being safe & Being safe \\
\hline \multirow{2}{*}{ Being healthy } & \multirow{2}{*}{ Being healthy } & Being functional \\
\hline & & Have a padronized caloric value \\
\hline
\end{tabular}

Table 1. Customer requirements to the functional dough for pies.

In the example of the functional dough for pies, it was constructed a table of deployment of the required qualities mainly from the joining of different sensory aspects of the product (Table 1).

\subsubsection{Establishment of the quality characteristics}

From the customer requirement of the tertiary level, must be extracted the technical characteristics of the finished product. At this point you have to convert the world of market into the technological world, drawing as much as possible, technical characteristics that will be easy to be measured. To do this, you should use the following reasoning: "How the required quality could be assessed in the final product?"

Then the table of quality characteristics should be built the same way as the table of the required qualities was. It should be built in groups thinking in the objectives of measurement or types of analysis to be carried out in the final product. For example, in the case of food products, in physico-chemical, microbiological and sensory analysis (Table 2). 


\begin{tabular}{|c|c|c|}
\hline Primary Level & Secondary Level & Tertiary Level \\
\hline \multirow{9}{*}{$\begin{array}{l}\text { Physico-chemical } \\
\text { characteristics }\end{array}$} & \multirow{9}{*}{$\begin{array}{l}\text { Physico-chemical characteristics } \\
\text { (cold dough) }\end{array}$} & Thickness of the dough for pie \\
\hline & & Diameter of the dough for pie \\
\hline & & Ash content \\
\hline & & Moisture of the dough for pie \\
\hline & & Baking time \\
\hline & & Fiber content \\
\hline & & Carbohydrate content \\
\hline & & Protein content \\
\hline & & Fat content \\
\hline \multirow{7}{*}{$\begin{array}{c}\text { Sensory } \\
\text { characteristics }\end{array}$} & \multirow{2}{*}{ Visual (baked dough) } & Color \\
\hline & & Integrity \\
\hline & \multirow{5}{*}{ Taste (baked dough) } & Aroma \\
\hline & & Neutral flavor \\
\hline & & Soft texture \\
\hline & & Crispness \\
\hline & & "Hollow" texture \\
\hline \multirow{4}{*}{$\begin{array}{l}\text { Microbiological } \\
\text { characteristics }\end{array}$} & \multirow{4}{*}{$\begin{array}{l}\text { Microbiological characteristics } \\
\text { (cold dough) }\end{array}$} & Coliforms at $45^{\circ} \mathrm{C}$ \\
\hline & & Salmonella sp/25g \\
\hline & & B. cereus \\
\hline & & Estafilococcus coagulase positive \\
\hline
\end{tabular}

Table 2. Table of quality characteristics of the dough for pies

\subsubsection{Establishing the correlations in the quality matrix}

In the central part of the matrix it's necessary to make the correlation of each required quality with each characteristic quality. To this must be observed the following rules:

1. Judge each relationship independently.

2. Assign symbols for each correlation which correspond to numeric values. The meanings can be:

(?) or 9: Strong correlation;

$\mathrm{O}$ or 6 : There is a correlation;

$\triangle$ or 3: Possible correlation

3. For each required quality should be at least one strong correlation.

4. The symbols can not be concentrated in one place only. 
5. There should not be an item excessively marked with symbols.

With this information it was possible to build the quality matrix of a functional ready to bake dough for pies (Picture 2). There was done a correlation between these required qualities by the market and the quality characteristics of the finished product, assigning values 3,6 or 9 .

\subsubsection{Establishment of the planned quality}

The first column of the planned quality is the degree of importance. This must be established by the survey with consumers of the target market. When the survey is done, it is necessary to launch the averages values obtained in the matrix.

In the example of the functional dough for pies, the degree of importance of the required qualities has been established through research with thirty-two prospective buyers, where the interviewed indicates how important each characteristic was on a scale from 1 (unimportant) to 5 (very important). The medians for each attribute were also launched into the matrix.

After the development of the prototypes in industrial kitchens or in a pilot plant, it should be performed a search for sensory analysis with a sample of the target market. For this, should perform an affective sensory test with samples of one or more developed prototypes and a competitor's product, if any.

In the survey of the sensory analysis can be used items of the second level of the table of deployment of required qualities. Based on the type of scale used in the sensory test, it should be launched into the matrix the averages or medians of the results of sensory analysis.

In the case of the functional dough for pies, for the sensory analysis of the products developed, it was used the test of acceptance by the hedonic scale, varying gradually from 1 to 9 , based on attributes like or dislike. Fifty tasters commented on all the attributes initially listed as important to the market. The medians of the attributes evaluated in the sensory analysis of the product developed were included in the matrix (Picutre 2). To compare the performance of the products developed for each required quality, we used nonparametric statistical test of Mann \& Whitney (Siegel \& Castellan, 2006) in order to distinguish the preferred.

Then you must define, through consensus among the development team, the column called planned quality, taking into account the degree of importance and the performance of the company and competitors. See the example in Picture 2.

The rate of improvement is established through the ratio between each value of planned quality by the performance of the product in the sensory analysis. Then it should be to establish which required qualities are considered strong, medium or weak selling points, i.e., which attributes will be attractive to the market, which items are attractive to the consumers in an average way and which attributes are obvious or mandatory to the product. In the column of the selling point, items considered to be attractive to the market receiving the note 1.5, intermediate items, the value 1.2 and those considered obvious, is assigned the value 1.0.

To calculate the absolute weight, multiply the degree of importance by the rate of improvement and also by the selling point. The relative weight of each required quality is the corresponding percentage of the absolute weight. 


\begin{tabular}{|c|c|c|c|c|c|c|c|c|c|c|c|c|c|c|c|}
\hline 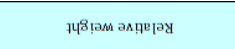 & $\bar{\tau}$ & $\stackrel{m}{\infty}$ & $\bar{i}$ & कृ & $\stackrel{9}{i}$ & $\stackrel{9}{r}$ & î & $\stackrel{2}{\circ}$ & $\stackrel{5}{\circ}$ & $\stackrel{9}{i}$ & $\stackrel{9}{1}$ & \begin{tabular}{l} 
\\
\multirow{1}{*}{}
\end{tabular} & $\stackrel{8}{\circ}$ & & \\
\hline 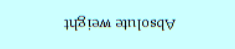 & $\stackrel{\circ}{m}$ & $\mathcal{\forall}$ & $\ddot{m}$ & $\stackrel{\circ}{\circ}$ & $\stackrel{\circ}{\dot{f}}$ & $\stackrel{\circ}{+}$ & $\stackrel{\circ}{m}$ & $\stackrel{\infty}{+}$ & $\stackrel{\infty}{+}$ & $\stackrel{\circ}{+}$ & $\stackrel{\circ}{\circ}$ & $\stackrel{\infty}{\sim}$ & 茴 & & \\
\hline 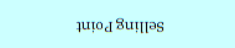 & $\cong$ & $\cong$ & $\stackrel{\dddot{Y}}{\longleftarrow}$ & $\stackrel{\circ}{-}$ & $\stackrel{\circ}{-}$ & $\stackrel{\circ}{-}$ & $\stackrel{\circ}{-}$ & $\dddot{\simeq}$ & $\stackrel{\simeq}{\longleftarrow}$ & $\stackrel{\circ}{-}$ & $\stackrel{\circ}{-}$ & $\stackrel{6}{-}$ & 密 & & \\
\hline 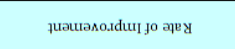 & $\stackrel{\circ}{-}$ & $\stackrel{\circ}{\circ}$ & $\stackrel{\circ}{-}$ & $\stackrel{\circ}{\circ}$ & $\stackrel{\circ}{\circ}$ & $\stackrel{\circ}{-}$ & $\stackrel{-}{-}$ & $\stackrel{\circ}{\circ}$ & $\stackrel{\circ}{\circ}$ & $\stackrel{0}{\circ}$ & $\stackrel{\circ}{-}$ & $\stackrel{\circ}{-}$ & & & \\
\hline 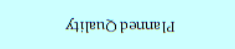 & 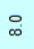 & $\stackrel{\circ}{\infty}$ & $\stackrel{\circ}{\circ}$ & $\begin{array}{l}0 \\
\infty\end{array}$ & $\stackrel{\circ}{\circ}$ & $\stackrel{\circ}{\infty}$ & $\stackrel{\circ}{\infty}$ & $\infty$ & $\stackrel{\circ}{\infty}$ & 음 & 우 & 우 & & & \\
\hline 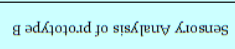 & ○ & $\begin{array}{l}0 \\
\infty\end{array}$ & $\begin{array}{l}0 \\
\infty\end{array}$ & 잉 & $\stackrel{\circ}{\circ}$ & ○ & $\stackrel{\circ}{\infty}$ & 웅 & 잉 & 음 & 웅 & 웅 & & & \\
\hline 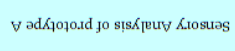 & $\infty$ & $\infty$ & $\begin{array}{l}0 \\
\infty\end{array}$ & 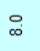 & $\stackrel{0}{\infty}$ & $\stackrel{\circ}{\infty}$ & $\stackrel{\circ}{\infty}$ & $\stackrel{\circ}{\infty}$ & $\stackrel{\circ}{\infty}$ & ㅇ. & 우 & 우 & & & \\
\hline 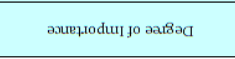 & $\stackrel{\text { mे }}{2}$ & $\stackrel{n}{m}$ & $\stackrel{\circ}{m}$ & 이 & $\stackrel{\circ}{+}$ & $\stackrel{\circ}{+}$ & $\stackrel{\circ}{m}$ & $\stackrel{\circ}{\rightarrow}$ & $\stackrel{\circ}{\rightarrow}$ & $\stackrel{\circ}{+}$ & $\stackrel{\circ}{+}$ & 오 & 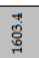 & : & \\
\hline 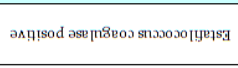 & & & & & & & & & & $a$ & & & 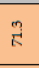 & $\ddot{H}$ & $\begin{array}{l}00 \\
0 \\
0 \\
0 \\
0\end{array}$ \\
\hline snаәə 'g & & & & & & & & & & $a$ & & & $\overrightarrow{2}$ & $\ddot{H}$ & 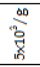 \\
\hline 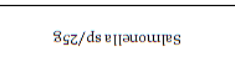 & & & & & & & & & & $\sigma$ & & & $\vec{\Sigma}$ & 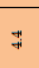 & 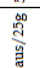 \\
\hline Dost te sutog̣!̣o & & & & & & & & & & $a$ & & & दे & $\underset{+}{H}$ & 兽 \\
\hline 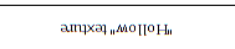 & $\infty$ & m & $a$ & & & & & & n & & & & 总 & के & $n$ \\
\hline ssaudșu & m & $a$ & on & & & & & & & & & & 号 & ?? & $n$ \\
\hline атихаң џов & $a$ & m & in & & & & & & & & & & 哭 & g: & $n$ \\
\hline 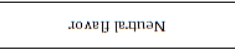 & & & & & & & $\circ$ & $a$ & & & & & ปี & $\stackrel{\circ}{\circ}$ & $n$ \\
\hline вuоo.ry & & & & & & & o. & in & & & & & ఫิ & in & $n$ \\
\hline құривауй & & & & & & & & & a. & & & & $\begin{array}{l}10 \\
108 \\
3\end{array}$ & in & 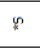 \\
\hline .10105 & & & & $a$ & & & & & & & & & in & के & $n$ \\
\hline aup suppeg & & & & & & & & & & & & & : & $:$ & \\
\hline ұиадиогедея & m & & in & & & & & $\circ$ & m & & $a$ & & $\begin{array}{l}0 \\
\text { శ్ } \\
\end{array}$ & 잉 & 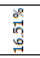 \\
\hline 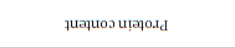 & & & & & & & & in & $\circ$ & & $a$ & & 营 & in & $\stackrel{\rightleftarrows}{\exists}$ \\
\hline 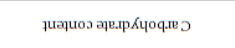 & & & & & & & & in & & & $a$ & & 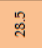 & $\stackrel{\infty}{+}$ & ๙ั้ \\
\hline 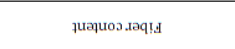 & $\infty$ & & & & & & & in & n & & & $a$ & तี่ & సี & 然 \\
\hline 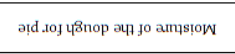 & & 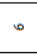 & & & & & & & in & $\bullet$ & & & 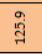 & : & 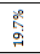 \\
\hline ұиадиоз чв४ & & & & $a$ & & & & & & & & & 然 & ले & : \\
\hline 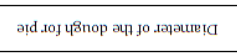 & & & & & $\sigma$ & & & & & & & & हे & $\#$ & 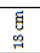 \\
\hline 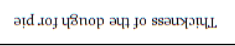 & in & n & & & & $a$ & & & & & & & 3a & iे & $\underset{+1}{\mathbb{8}}$ \\
\hline 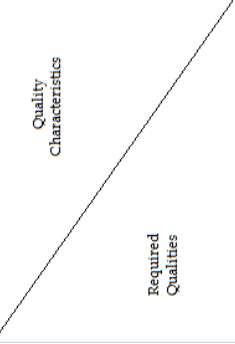 & 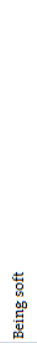 & 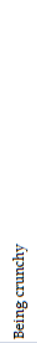 & 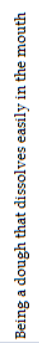 & 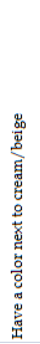 & 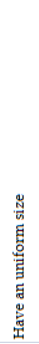 & 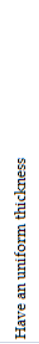 & 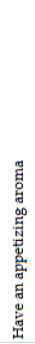 & 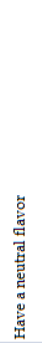 & $\begin{array}{l}\text { 急 } \\
\text { 号 } \\
\text { 离 }\end{array}$ & 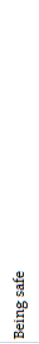 & 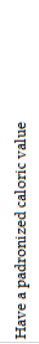 & 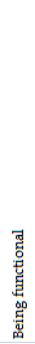 & 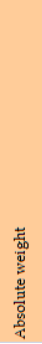 & 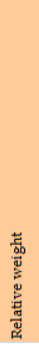 & 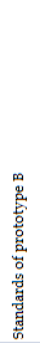 \\
\hline
\end{tabular}

Fig. 2. Quality Matrix of a functional ready to bake dough for pies 


\subsubsection{Establishment of the designed quality}

Now, it should be calculated the absolute weight of the quality characteristics at the bottom of the quality matrix. To do this, multiply the relative weight of each required quality by the numerical values of correlations, and add up these products vertically. The relative weight of each quality characteristic is the corresponding percentage of the absolute weight. For example, in Picutre 2, the absolute weight of 46.3 of the quality characteristic "dough thickness" was calculated by multiplying $(7.1 \times 3)+(8.3 \times 3)+(7.9 \times 9)$.

In the case of the functional dough for pies, were established physico-chemical, microbiological and sensory specifications for each quality characteristic of the finished product. The physico-chemical specifications were obtained by laboratory tests. The microbiological standards have been established according to the Brazilian law and the sensorial by a trained sensorial team.

\section{Overview of the application of QFD in food products}

QFD has been used in the food industry since 1987, i.e., its use is recent (Costa et al., 2001). But only after the 90 's is that the articles were published showing the benefits of using the method in food products (Benner et al., 2003).

According to Souza Filho and Nantes (2004), the literature has dealt with much more organizational benefits and potential for improving the technical quality than the implementation process of QFD. Few articles describe how QFD has been used in real products and discuss their own experiences. Thus there isn't a deeper theoretical in the application of this method. To Charteris (1993) and Govers (1996), the strategic importance of QFD to contribute to the competitive advantage of firms may explain the reluctance of companies to share such important information on QFD.

Importantly, too, that one factor, perhaps one of the main, is the difficulty of finding scientific study of the application of QFD into the food industry, is due to the reliance on specific sensory attributes of each product. QFD was originally developed for the development of boats, automobiles and automobiles pieces. The technical characteristics related to this type of product are characteristics that have defined shapes and dimensions, specifications and parameters that can be measured accurately. However, the area of food has a different characteristic; the food may have different perceptions of consumer to consumer. Sensory perceptions are intrinsic to every human being and despite the food being technical specifications, mainly physico-chemical and microbiological parameters, the sensory perceptions are very difficult to specify. Allied to this, food ingredients have slightly larger deviations than pieces of heavy industry and those may change due to interactions between them or due to the process applied (Favaretto, 2007). Thus, the technicians of the food industry wishing to use the QFD tool must idealize the necessary changes in the method so that it becomes applicable in the development of a food product. It is important that simplifications are made to the product, its ingredients and their interactions so that the matrices can be used without any difficulty.

Cheng \& Melo Filho (2010), in a survey on the contour and depth of application of QFD in the 500 largest Brazilian companies, came to the conclusion that is recent the introduction of the method in those companies and that is still a long way to go and a need for greater understanding and support of top management in the implementation of this method by companies.

Although the use of QFD is recent, some companies, however, begin to realize the advantages of their use and are already getting great results with the implementation of the 
method. Table 3 presents some applications of QFD in food product development in the last 12 years.

\begin{tabular}{|c|c|c|}
\hline Authors & Applications of QFD & Results of the use of QFD \\
\hline Antoni (1999) & $\begin{array}{l}\text { Turkey dry } \\
\text { fermented sausage }\end{array}$ & $\begin{array}{l}\text { Easy understanding of the real needs to } \\
\text { be addressed in the product. } \\
\text { Interpretation of the first Quality Matrix } \\
\text { as the voice of the customer divided into } \\
\text { two parts: final consumer requirements } \\
\text { and demands of the point of sale, } \\
\text { unfolding them into the final product } \\
\text { characteristics. Correlation between the } \\
\text { raw material characteristics and the final } \\
\text { product characteristics. }\end{array}$ \\
\hline $\begin{array}{c}\text { Viaene \& } \\
\text { Januszewska (1999) }\end{array}$ & Chocolate couverture & $\begin{array}{l}\text { Approximation of the areas of } \\
\text { Marketing and of Food Science and } \\
\text { Technology, reduction of the final cost } \\
\text { and increase of the success potential in } \\
\text { launching the new product due to the } \\
\text { participation of } \\
\text { the consumers belonging to this target } \\
\text { segment into the process. }\end{array}$ \\
\hline $\begin{array}{l}\text { Tumulero et al. } \\
\qquad(2000)\end{array}$ & Salty crackers & $\begin{array}{l}\text { Product improvement, sales } \\
\text { increase and expansion of market share. }\end{array}$ \\
\hline $\begin{array}{l}\text { Marcos (2001); } \\
\text { Marcos \& Jorge } \\
\quad(2002)\end{array}$ & Table Tomato & $\begin{array}{l}\text { Higher interaction of functional areas } \\
\text { involved in the development process } \\
\text { and establishment of sales strategies } \\
\text { based on the analysis of the consumer } \\
\text { market. Reduction of losses. }\end{array}$ \\
\hline Chaves (2002) & Yogurt & $\begin{array}{l}\text { Identification of the most important } \\
\text { aspects from the standpoint of quality. } \\
\text { Translation of the needs and desires of } \\
\text { customers and structural changes to } \\
\text { meet the expectations of a specific } \\
\text { market. }\end{array}$ \\
\hline Magalhães (2002) & $\begin{array}{c}\text { Packaged } \\
\text { pasteurized milk }\end{array}$ & Increase on the sales of the product \\
\hline $\begin{array}{l}\text { Stewart-Knox \& } \\
\text { Mitchell (2003) }\end{array}$ & $\begin{array}{l}\text { Food products with } \\
\text { reduced fat }\end{array}$ & $\begin{array}{l}\text { Market identification, consumer } \\
\text { awareness and participation of } \\
\text { suppliers. }\end{array}$ \\
\hline
\end{tabular}

Table 3. Applications of QFD in food product development 


\begin{tabular}{|c|c|c|}
\hline Authors & Applications of QFD & Results of the use of QFD \\
\hline $\begin{array}{c}\text { Cortés \& Da Silva } \\
\qquad(2005)\end{array}$ & Yogurt & $\begin{array}{l}\text { Translation of customer requirements } \\
\text { and restructuring of the product } \\
\text { according to market expectations. } \\
\text { Commitment of all members of the } \\
\text { company. }\end{array}$ \\
\hline $\begin{array}{l}\text { Gonçalves \& Silva } \\
\text { (2005) }\end{array}$ & $\begin{array}{c}\text { Production of meals: } \\
\text { integration of QFD x } \\
\text { APPCC }\end{array}$ & $\begin{array}{l}\text { Identification of the potential dangers } \\
\text { of contamination in the generic process } \\
\text { to produce meals. Verification of the } \\
\text { phases of meals production that require } \\
\text { greater attention from staff. The results } \\
\text { of the items prioritized in the matrix } \\
\text { served as an aid in the selection and } \\
\text { training process of employees. }\end{array}$ \\
\hline $\begin{array}{l}\text { Waisarayutt \& } \\
\text { Tutiyapak (2006) }\end{array}$ & Instant rice noodles & $\begin{array}{l}\text { Based on customer requirements, } \\
\text { determination of the most important } \\
\text { technical specifications of the product } \\
\text { and the important parameters of the } \\
\text { process. Development of control plans } \\
\text { in accordance with the process } \\
\text { parameters. }\end{array}$ \\
\hline $\begin{array}{l}\text { Delgado \& Pedrozo } \\
\text { (2007) }\end{array}$ & $\begin{array}{c}\text { Micro food company } \\
\text { in Peru, "Delicias del } \\
\text { Sur". }\end{array}$ & $\begin{array}{l}\text { Identification of customer needs and } \\
\text { competitors' actions. Development of } \\
\text { new food products based on } \\
\text { differentiation through the } \\
\text { incorporation of raw materials and } \\
\text { inputs from local resources of } \\
\text { functional character. Strengthening } \\
\text { relationships in the areas of the } \\
\text { organization. }\end{array}$ \\
\hline Favaretto (2007) & Soft drink & $\begin{array}{l}\text { Decrease in the time of product } \\
\text { development, quality assurance of } \\
\text { product and service offered to the } \\
\text { customers. Culture change in the } \\
\text { organization. }\end{array}$ \\
\hline $\begin{array}{l}\text { Ferreira \& Miyaoka } \\
\qquad(2007)\end{array}$ & $\begin{array}{l}\text { Sweet Milk based on } \\
\text { soy }\end{array}$ & $\begin{array}{l}\text { Identification of real needs and desires } \\
\text { of the audience. Serving an attractive } \\
\text { niche market, who are lactose } \\
\text { intolerant, vegetarians and people } \\
\text { seeking a healthier diet. Improved } \\
\text { quality and cost reduction. }\end{array}$ \\
\hline
\end{tabular}

Table 3. (continued): Applications of QFD in food product development 


\begin{tabular}{|c|c|c|}
\hline Authors & Applications of QFD & Results of the use of QFD \\
\hline Matsunaga (2007) & Breaded chicken & $\begin{array}{l}\text { Identification of the attributes most } \\
\text { valued by consumers. Higher } \\
\text { interaction between research and } \\
\text { product development area and } \\
\text { marketing area. }\end{array}$ \\
\hline Miguel et al., (2007) & $\begin{array}{l}\text { Consumer profile of } \\
\text { pineapple "Pérola" }\end{array}$ & $\begin{array}{l}\text { Identification of critical quality } \\
\text { attributes at the purchase time, } \\
\text { establishment of the degree of } \\
\text { importance of each attribute required } \\
\text { by the market and interpretation of } \\
\text { sensory analysis. Identification of } \\
\text { points to be improved within the } \\
\text { supply chain, minimizing losses and } \\
\text { maintaining and improving the quality } \\
\text { of the final product. }\end{array}$ \\
\hline Anzanello et al., (2009) & Christmas turkey & $\begin{array}{l}\text { Identification of the process } \\
\text { parameters, product and resources to } \\
\text { be prioritized in the adoption of } \\
\text { improvements. Identification of } \\
\text { resources seen as bottlenecks to meet } \\
\text { the demands prioritized in QFD. Global } \\
\text { view while driving improvements in } \\
\text { products. }\end{array}$ \\
\hline $\begin{array}{l}\text { Cheng \& Melo Filho } \\
\qquad(2010)\end{array}$ & $\begin{array}{l}\text { Noble products with } \\
\text { embedded (ready } \\
\text { dishes like ham } \\
\text { lasagna) }\end{array}$ & $\begin{array}{l}\text { Anticipating the possible changes of } \\
\text { habits and attitudes, adding value to } \\
\text { the product. }\end{array}$ \\
\hline Garcia (2010) & Fluid milk & $\begin{array}{c}\text { Disclosure of the characteristics to be } \\
\text { worked in order to improve product } \\
\text { quality. }\end{array}$ \\
\hline Kawai (2010) & Table tomato & $\begin{array}{l}\text { Identification of the required } \\
\text { characteristics by consumers and the } \\
\text { establishment of a competitor that has } \\
\text { the largest market share. Reduce losses } \\
\text { and increase the income of the } \\
\text { producer. Improved communication } \\
\text { between sectors. }\end{array}$ \\
\hline Pinto \& Paiva (2010) & $\begin{array}{l}\text { Functional dough } \\
\text { ready for pies }\end{array}$ & $\begin{array}{l}\text { Identification of the characteristics that } \\
\text { consumers attach as of greater } \\
\text { importance and prioritization those } \\
\text { into the product development. }\end{array}$ \\
\hline
\end{tabular}

Table 3. (continued): Applications of QFD in food product development 


\begin{tabular}{|c|c|c|}
\hline Authors & Applications of QFD & Results of the use of QFD \\
\hline Rodrigues (2010) & $\begin{array}{c}\text { Improving food } \\
\text { services at the } \\
\text { Universidade } \\
\text { Estadual de } \\
\text { Campinas (Unicamp) }\end{array}$ & $\begin{array}{c}\text { Identification of the quality } \\
\text { characteristics most important and } \\
\text { which should be tailored to the } \\
\text { improvement of food service } \\
\text { establishments of Unicamp. Improved } \\
\text { workflow and execution of solutions } \\
\text { more quickly and affordably. }\end{array}$ \\
\hline $\begin{array}{c}\text { Vatthanakul et al., } \\
(2010)\end{array}$ & $\begin{array}{c}\text { Product of gold } \\
\text { kiwifruit leather }\end{array}$ & $\begin{array}{c}\text { Defining the importance of the various } \\
\text { sensory characteristics for the design of } \\
\text { new products. }\end{array}$ \\
\hline Zarei et al., (2011) & Canning industry & $\begin{array}{c}\text { Identification of enablers of Lean } \\
\text { Manufacturing viable to be } \\
\text { implemented in practice in order to } \\
\text { increase the lean production of food } \\
\text { supply chain. }\end{array}$ \\
\hline
\end{tabular}

Table 3. (continued): Applications of QFD in food product development

Based on the work presented, it is emphasized that QFD enables the company to develop products that meet the diverse and growing demands of its customers, serving different market niches, in a short time, and is characterized by the efficiency in storage and transmission of information during the multifunctional product development activity. In addition, the use of the method QFD in several companies have pointed out others advantages as: resolving problems, reducing the development time and using of prototypes in a more objective way. The QFD is effective in order to direct, in a practice way, how to plan and conduct activities necessary to the process of the product development.

\section{Sensory analysis and support tools to market research}

The application of QFD in the food industry is complex and the literature does not allow establishing its full application in the development of these products. For this reason, adaptations that take into account the characteristics of the product "food" are necessary for the successful implementation of QFD in this industry. The adjustments should pursue a better integration of aspects of market research with the sensory evaluation of food, aiming to reveal the perception of consumers in a jointful way, in relation to the general market attributes (shape, size, ease of use, etc.) and to the sensory attributes that make them decide to accept and purchase of food. The integration of these aspects should also consider the current model of food consumption in the region and the market segment defined for the product.

In developing a new product is essential to optimize parameters such as shape, color, appearance, odor, flavor, texture, consistency and the interaction of different components, in order to achieve a full balance that translates into an excellent quality and have good acceptability. Thus, according to Monteleone and colleagues (1997), studying the relationships between the sensory attributes and the acceptance of a product can be very useful to formulate or improve a product, as well as to evaluate potential market opportunities. Understanding what drives the acceptance of a product is very important in light of a competitive market like nowadays. Meeting the most valued attributes makes 
more oriented the product development, benefiting not only the area of research and product development, as well as marketing, reducing distances between these two areas. In this sense, the methods of sensory evaluation of foods and evaluation of consumer desires can be an aid when applied the method QFD into the food product development.

In sensory analysis the differences between products (discriminatory tests), the intensity of a sensory attribute of quality (descriptive tests), or the degree of acceptance, preference or rejection for a product (affective tests) are measured by human senses. However, it is necessary to consider that the sensory perceptions can not be measured directly. Therefore to assess the individual stimulation received in the sensory evaluation is used scales that allow the quantification of them, as the specific objective of the evaluation (Bech et al. 1994; Chaves \& Sproesser, 1996; Ferreira et al. 2000).

In acceptance tests, the hedonic scale is the most used and widespread. It is a structured scale, with nine sentences, balanced, considered easy to use and to understand (says the pleasant and unpleasant states in the body). The evaluation of the hedonic scale is converted into numerical scores, and statistically analyzed to determine the difference in the degree of preference between samples (ABNT, 1998, IFT, 1981; Land \& Shepherd, 1988). Optionally you can use the hybrid hedonic scale, a continuous scale of $10 \mathrm{~cm}$, and with the advantages to meet the assumptions of the models of analysis of variance (ANOVA) as the normality of the residuals and homoscedasticity, and increase the discrimination between the samples. The traditional methodologies for analyzing the affective tests data, like the ANOVA, used to compare more than two averages in the study, and the averages test, to determine the significance to a particular level of confidence, have shown limitations and shortcomings. For each product evaluated is obtained the average of the consumer's group, assuming therefore that all respondents have the same behavior, ignoring their individuality. Thus, there may be occurring loss of important information about different market segments (Meilgaard et al. 2006; Polignano et al., 1999, Reis \& Minim, 2006).

In order to analyze the affective data, taking into account the individual response of each consumer and not just the average of the consumer group that evaluated the products, it was developed a technique called Preference Mapping, which has been widely used by scientists of the area of sensory analysis (Behrens et al., 1999). This technique is often employed to identify groups of consumers who respond uniformly and that differ from other groups by age, sex, attitude, need, eating habits and/or responses to the product's attributes. This gives the opportunity to interpretate the different areas of action of the market (Polignano, 2000, Westad et al., 2004).

As it can explain better the consumer preference for each attribute, the Preference Mapping is an interesting tool to collect the real needs of customers and turn them into project qualities. It can be very useful during the development of food products, particularly in the construction phase of the Designed Quality of the Quality Matrix (Polignano, 2000).

Cluster analysis is a set of statistical techniques whose objective is to seek a classification according to the natural relations that the sample shows, forming groups of objects (individuals, companies, cities or other experimental unit) according to the similarity in relation to some predetermined criteria, thus reducing the dimensionality of the data. According to Hair et al. (1998), the groupings (or clusters) resultants should have a high internal homogeneity (within groups) and high external heterogeneity (between groups). Cluster analysis is useful in developing new products to meet consumer profiles. This can identify the profile of each group (age, marital status, psychological characteristics, etc.) that 
will define whether there are different demands (market segmentation). The profile is defined by the characteristics that make up the cluster, based on the concept of similarity. In addition to these approaches, there is the publication of articles dealing with the use of Conjoint Analysis in the food industry. The Conjoint Analysis is a technique that allow to study the combined effect exerted by two or more independent variables on a dependent variable (Carneiro et al., 2003). Based on a decomposition analysis, the Conjoint Analysis determines the contribution of the studied factor levels expressed in samples or combinations of the consumer response (acceptance, preference or purchase intent). It is an analysis technique that can be used to identify the attributes/levels that most influence the selection, purchase and acceptance of products, after the sensory evaluation of them.

The Conjoint Analysis has been widely applied in the development of new products in all industrial sectors, in particular in the establishment of concepts, competitive analysis, selection of target market segment, the definition of price and advertising strategy (Drummond, 1998).

Another tool that has been used is the Repertory Grid. Kelly presented it in 1955, which advocates the theory that people act as scientists evaluating the world around them, creating hypotheses and establishing descriptors of what it is seen. The Repertory Grid method is a term used to describe a set of techniques related to the Kelly's theory (1955), which can be used to investigate the individual definitions in the perception of characteristics of his surroundings. This method is very flexible and allows it to be applied according to the researcher's interest (Mac Fie \& Thomson, 1994).

A descriptor is defined as the way in which two items are similar and, in some way, different from a third party. In the sensory field, the samples are arranged in triads. In each set, two samples are kept together and one away from the taster and it describes how the samples are alike and how different. In addition to identifying the differences, the tasters should also describe the extremes of each descriptor raised, in order to build a scale so that samples can be quantified. The data collected are analyzed by GPA (Generalized Procrustes Analysis), which allow to be established a configuration with the main and common descriptors to the tasters. This is a multivariate analysis, that establish the consensus map of the data (Mac Fie \& Thomson, 1994).

Another method that helps to identify the product perception by the consumer is called Focus Group. Focus Group can be defined as a planned session to obtain individual perceptions of such a product or service, in a peaceful environment, through the moderation of groups formed by six to nine people (Macfie \& Thomson, 1994) or eight to twelve people (Fuller, 2011). It is a qualitative technique of group discussion, which allows interaction between people. The moderator leads the discussion to the topics of interest, listening to people, without interfering directly. This technique allows to raise the participants' perceptions about the subject matter. According to Fuller (2011), the main function of the Focus Group is to determine consumer reaction to the objects of study.

The Kano method has as it's main goal to evaluate the influence of components of products in consumer satisfaction (Sauerwein et al., 1996). This method aims to rank the attributes in four characteristics groups according to the degree of care and satisfaction: indifferent (characteristics that do not affect consumer satisfaction), expected (mandatory characteristics), proportional (characteristics that customer satisfaction is proportional to the degree of care) and attractive (characteristics that customer satisfaction does not diminish if not offered, but increases if met) (Fonseca, 2002). 
Using this model it is possible to improve the process of understanding the requirements from a classification that can help prioritize development resources. The identification of mandatory requirements for certain attributes and opportunities of future innovation, which customers have not even being classified as needs now, allowing the development and the use of criteria in a more efficient way for resource allocation. The process of translating requirements into product characteristics or services should also benefit from the information obtained using the Kano model (Guimarães, 2003).

Kano helps in the process of product development, prioritizing the characteristics that really have an impact on customer satisfaction. Beyond that, this may be very well combined with QFD, identifying the relative importance of the needs raised by consumers, contributing to the product development more focused and better targeted to the audience. The classification of characteristics can also be a guideline to define the attributes to be worked out for different market segments, creating product differentiation in that market.

\section{Conclusion}

The effective development of products has become the competitive advantage for many companies, especially in the food industry. For that, as shown in this chapter, projects must achieve the best levels of quality, of efficiency and speed in the elaboration of products. Certainly this requires an organizational effort of the entire company. What the firm plans, i.e., its development strategy, and how the company makes its planning - its development management - will determine the expressiveness of the product in the market. In this sense, it can be affirmed that the competitive advantage of these organizations is based on the capacity of its technical staff, in the procedures and organizational structure, in the strategies established to guide the process, in the methods used, in the way that the top management interacts with the process and yet, in the organization of the team according to the level of complexity of the project.

The QFD method as pointed out in this work is not a mechanism that addresses all of the aspects above, important for structuring the system of product development. However, by offering a way to treat the necessary information to the process and to plan the activities, the method has boosted the development system in several companies.

Ultimately, it is worth noting that, specifically for the food industry, some aspects can enhance the use of the method. Among them those can be mention:

Existence of a support infrastructure to the process, with sufficiently equipped laboratories and trained personnel to conduct the analysis.

The intrinsic quality of food products can be evaluated by physico-chemical, microbiological and sensory analyses. Thus, the values of the quality characteristics during construction of the matrices are determined by such methods. Various techniques of sensory analysis assist in analyzing and gathering market information and then building a quality matrix, as reported in this chapter.

Likewise, the pilot plants and experimental kitchens within companies, contribute greatly to the development of prototypes and conduction of activities in a more quickly way.

Knowledge and application of various statistical techniques in the process of product development. 
Such techniques facilitate the identification of opportunities and strategic positioning of products, the identification of factors that affect customer preference and the market segmentation, supporting the use of the QFD method.

Assurance system of the consolidated quality

The consolidated quality management benefits directly the development process, as it aims to optimize the exchange of information, the commitment of the people involved in the activities, the specification of process parameters and the standardization of this procedures, as well, developing products with little variability. Certainly, these factors create a safer environment for the conduct of projects, facilitating, in particular, the specification of product technical parameters, of raw materials, packaging and of the manufacturing process.

\section{References}

ABNT (1998). Associação Brasileira de Normas Técnicas. NBR 14141: escalas utilizadas em análise sensorial de alimentos e bebidas. Rio de Janeiro, 1998.

Akao, Y. \& Mazur, G. (2003).The leading edge in QFD: past, present and future. International Journal of Quality \& Reliability Management. Vol. 20, No.1, pp. 20-35, ISSN 0265-671X.

Akao, Y. \& Ohfuji, T. (1989). Recent aspects of Quality Function Deployment in service industries in Japan. Proceedings of the International Conference on Quality Control, ISBN 0-915299-41-0 3, Rio de Janeiro, 1989.

Antoni, I. (1999). Desenvolvimento de um Embutido Fermentado de Carne de Peru pelo Método do Desdobramento da Qualidade. 136 p. Dissertação (Mestrado em Tecnologia de Alimentos). Faculdade de Engenharia de Alimentos, Universidade Estadual de Campinas (Unicamp), Campinas.

Anzanello, M.; Lemos, F. \& Encheveste, M. (2009). Aprimorando Produtos Orientados ao Consumidor Utilizando Desdobramento da Função Qualidade (QFD) e Previsão de Demanda. Produto \& Produção, Vol. 10, No. 2, jun., 2009, pp. 01 - 27, ISSN 1516-3660.

Athayde, A. (1999). Indústrias agregam conveniências aos novos produtos. Engenharia de Alimentos, São Paulo, Vol. 24, 1999, pp. 39-41.

Bech, A.; Engelund, E.; Juhl, J.; Kristensen, K. \& Poulsen, C. (1994). QFood-optimal design of food products. MAPP working Paper no.19. MAPP Centre, Aarhus. March, 1994; pp. 2-12; ISSN 09072101.

Behrens, J.; Silva, M. \& Wakeling, I. (1999). Avaliação da aceitação de vinhos brancos varietais brasileiros através de testes sensoriais afetivos e técnica multivariada de mapa de preferência interno. Revista da Sociedade Brasileira de Ciência e Tecnologia de Alimentos, Campinas, Vol. 19, No. 2, May, 1999, ISSN 0101-2061.

Benner, M.; Linnemann, A.; Jongen, W. \& Folstar, P. (2003). Quality function deployment (QFD) - can it be used to develop food products?, Food Quality and Preference, Netherlands, Vol. 14, pp. 327-339, ISSN 0950-3293.

Carneiro, J.; Silva, C.; Minim, V.; Regazzi, A.;Deliza, R. \& Suda, I. (2003). Princípios básicos da Conjoint Analysis em estudos do consumidor. Revista da Sociedade Brasileira de Ciência e Tecnologia de Alimentos, Campinas, Vol. 37, No. supl, 2003, pp. 107-114, ISSN 0101-2061.

Chan, L. \& Wu, M. (2002). Quality function deployment: a literature review. European Journal of Operational Research, Vol. 143, 2002, pp. 463-497, ISSN 0377-2217. 
Charteris, W. (1993). Quality function deployment: a quality engineering technology for the food industry. Journal of the Society of Dairy Technology, Vol.46, No 1, 1993, February, 1993, pp. 12-21, ISSN 0037-9840.

Chaves, J. \& Sproesser, R. (1996) Práticas de laboratório de análise sensorial de alimentos e bebidas. Publisher: UFV, Viçosa, Brazil.

Chaves, O. (2002). Aplicação do método de desdobramento da função qualidade na industrialização do leite de consumo em Minas Gerais. 86 p. Dissertação (Mestrado em Economia Rural). Departamento de Economia Rural, Universidade Federal de Viçosa, Viçosa.

Cheng, L. \& Melo Filho, L. (2010). QFD: desdobramento da função qualidade na gestão de desenvolvimento de produtos. (2 ed). Publisher: Blucher, ISBN 9788521205418, São Paulo.

Clark, K. \& Wheelwright. S. (1993). Managing new product and process development. Free Press, ISBN 0-02-905517-2, New York.

Cooper, R. (2001). Winning at new products. Accelerating the process from idea to lanch. ( $\left.3^{\mathrm{a}} \mathrm{ed}\right)$, Publisher: Basic Books. Cambridge, Massachusetts. ISBN 0738204633.

Cortés, D. \& Da Silva, C. (2005). Revisão: Desdobramento da Função Qualidade - QFD conceitos e aplicações na indústria de alimentos. Brazilian Journal Food Technology, Vol. 8, No. 3, 2005, pp. 200-209, ISSN 1517-7645.

Costa, A.; Dekker, M. \& Jongen, W. (2001). Quality function deployment in the food industry: a review. Trends in Food Science and Technology, Vol.11, No. 9-10, 2001, pp. 306-314, ISSN 0924-2244.

Delgado, G. \& Pedrozo, E. (2007). Inovação de Produtos Alimentícios: Alimentos funcionais a partir de produtos locais. Proceedings of IV Convibra: Brazilian Administration Virtual Congress, São Paulo/SP. Brazil, dez., 2007.

Drumond, F. (1998). Ténicas Estastísticas para o Planejamento do Produto. Fundação Christiano Ottoni, Belo Horizonte.

Earle, M. (1997). Changes in the food product development process. Trends in Food Science $\mathcal{E}$ Technology, Vol. 8, 1997, pp. 19-24, ISSN 0924-2244.

Favaretto, R. (2007). Modelo de aplicação de QFD no desenvolvimento de Bebidas. 96 p. Dissertação (Mestrado em Profissional em Engenharia Mecânica) - Faculdade de Engenharia Mecânica, Universidade Estadual de Campinas (Unicamp), Campinas.

Ferreira, G. \& Miyaoka, A. (2007). Estratégias de desenvolvimento do doce de leite à base de soja. 30 p. Monografia (Graduação no Curso de Engenharia de Produção). Engenharia de Produção da Universidade Federal de Viçosa, Viçosa

Ferreira, V.; Almeida, T.; Pettinelli, M.; Silva, M.; Chaves, J. \& Barbosa, E. (2000). Análise sensorial: testes discriminativos e afetivos. Sociedade Brasileira de Ciência e Tecnologia de Alimentos, Campinas.

Fonseca, M. (2002). Uma abordagem para a redução de custos no desenvolvimento de produtos alimentícios. 82 p. Tese (Mestrado em Engenharia de Produção). Faculdade de Engenharia de Produção, Universidade Federal do Rio de Janeiro, Rio de Janeiro.

Fuller, G. (2011). New food product development: from concept to marketplace. (3ed.), CRC Press, ISBN 13:978-1-4398-1865-7, Florida.

Garcia, A. (2010). Uso do método DFQ (Desdobramento da Função Qualidade) para melhoria da qualidade do leite fluido. 181 p. Tese (Doutorado em Tecnologia de Alimentos). Faculdade de Engenharia de Alimentos, Universidade Estadual de Campinas, Campinas.

Gonçalves, T. \& Silva, C. (2005). Proposta de utilização do quality function deployment (QFD) no sistema de análise de pontos críticos de controle (APPCC) na produção de refeições. Proceedings of XII SIMPEP, Bauru, SP, Brazil, Nov., 2005. 
Govers, C. (1996). What and how about quality function deployment (QFD). International Journal of Production Economics, New York, Vol.46-47, 1996, pp. 575-585, ISSN 09255273.

Guimarães, L. (2003). QFD - Analisando seus aspectos culturais organizacionais. Revista Qualidade, Vol., No. 128, Jan., 2003, pp.56-66.

Hair J.; Anderson, R.; Tatham, R. \& Black, W (1998). Cluster analysis. In: Multivariate data analysis. Hair, J, Black, B, Babin, B \& Anderson, R (5.ed.), pp. 469-518, Prentice Hall, Upper Saddle River.

IFT. (1981). Sensory Evaluation Division. Guidelines for the preparation and review of paper reporting sensory evaluation date. Journal of Food Technology, Vol.35, No.4, 1981, pp.16-17, ISSN 0022-1163.

Kawai, S. (2010). Desenvolvimento de Tomate de Mesa, com o uso do método QFD (Quality Function Deployment), comercializado em um supermercado. 217 p. Tese (Doutorado em Tecnologia Pós-Colheita). Faculdade de Engenharia Agrícola. Universidade Estadual de Campinas, Campinas.

Macfie, H. \& Thomson, D. (1994). Measurement of food preferences. (1ed.), Springer, ISBN 9780834216792, New York.

Magalhães, G. (2002). Incorporação da Qualidade Desejada pelos Consumidores ao Leite Pasteurizado Utilizando o Desdobramento da Função Qualidade. 77 p. Dissertação (Mestrado em Ciência e Tecnologia de Alimentos). Programa de Pós-Graduação em Ciência e Tecnologia de Alimentos. Universidade Federal de Viçosa, Viçosa.

Marcos, S. \& Jorge, J. (2002). Desenvolvimento de tomate de mesa, com o uso do método QFD (Desdobramento da Função Qualidade), comercializado em um supermercado. Horticultura Brasileira, Brasília, v. 20, n. 3, p. 490-496, setembro 2002.

Marcos, S. (2001) Desenvolvimento de tomate de mesa, com o uso do método QFD (Quality Function Deployment), comercializado em um supermercado. $199 \mathrm{f}$. Tese (Doutorado em Ciência de Alimentos). Faculdade de Ciência de Alimentos. Universidade Estadual de Campinas, Campinas.

Matsunaga, P. (2007). Identificação de atributos sensoriais de pedaços empanados de frango mais valorizados pelo consumidor. 121p. Dissertação (Mestre em Alimentos e Nutrição). Faculdade de Engenharia de Alimentos. Universidade Estadual de Campinas, Campinas.

Meilgaard, M.; Civille, G. \& Carr, B. (2006). Sensory Evaluation Techniques, ( 4. ed.), FL: CRC Press, ISBN 0849338395, Boca Raton.

Melo Filho, L. \& Cheng, L. (2007). QFD na garantia da qualidade do produto durante seu desenvolvimento: caso em uma empresa de materiais. Produção, Vol. 17, No.3,Dec., 2007, . p. 604-624, ISSN 0103-6513.

Miguel, A.; Spoto, M.; Abrahão, C. \& Silva P. (2007) Aplicação do método QFD na avaliação do perfil do consumidor de abacaxi "Pérola". Ciência e Agrotecnologia, Vol. 31, No. 2, 2007, pp. 563-569, ISSN 1413-7054.

Mizuno, S. (1969). Company-wide quality control activities in Japan. Reports of Statistical Application Research, Vol.16, No.3, 1969, pp.68-77.

Monteleone, E.; Carlucci, A.; Caporale, G. \& Pagliarini, E. (1997). Use of slope analysis to characterize preference for virgin olive oil. Italian Journal of Food Service, Vol. 9, No. 2, 1997, pp. 133-140, ISSN 1120-1770.

Pinto, A. \& Paiva, C. (2010). Developing a functional ready to bake dough for pies using the Quality Function Deployment (QFD) method. Revista da Sociedade Brasileira de 
Ciência e Tecnologia de Alimentos, Campinas, Vol.30, No.(Supl.1), mai., 2010, pp 3643, ISSN 0101-2061.

Polignano, L. (2000). Desenvolvimento de produtos alimentícios: implentação da ferramenta mapa de refrência e estudo da sua articulação com a matriz da qualidade. 268 p. Dissertação (Mestre em Engenharia de Produção). Escola de Engenharia. Universidade Feredal de Minas Gerias, Minas Gerais.

Polignano, L.; Cheng, L. \& Drumond, F. (1999). Utilização dos mapas de preferência como técnicas auxiliares do QFD durante o desenvolvimento de produtos alimentícios. Proceedings of I Brazilian Conference on Management of Product Development, Belo Horizonte, Brazil, 1999.

Reis, C. \& Minim, V. (2006) Testes de aceitação. In: Análise sensorial: estudos com consumidores., Minim V., pp. 67-83, Publisher UFV, ISBN 85-7269-282-7, Viçosa, Brazil.

Rodrigues, N. (2010). Aplicação da matriz da qualidade do QFD - Desdobramento Da Função Qualidade - para avaliar serviços de alimentação do campus da Unicamp. 190 p. Tese (Doutorado em Tecnologia Pós-Colheita). Faculdade de Engenharia Agrícola. Universidade Estadual de Campinas, Campinas.

Sauerwein, E.; Bailom, F.; Matzler, K. \& Hinterhuber, H. (1996). The Kano Model: how to delight your consumers. Preprints of the IX International Working Seminar on Production Economics, Innsbruck/Igls/Austria, February, 1996.

Siegel, S. \& Castellan Jr, N. (2006). Estatística não-paramétrica para ciências do comportamento. (2 ed), Artmed, ISBN 85-363-0729-3, Porto Alegre.

Souza Filho, M. \& Nantes, J. (2004). O QFD e a análise sensorial no desenvolvimento de produtos. Proceedings of Production Engineering Symposium, Bauru, Nov., 2004.

Stewart-Knox, B. \& Mitchell, P. (2003). What separates the winners from the losers in new food product development? Trends in Food Science and Technology, Vol. 14, No.1-2, 2003, pp. 58-64, ISSN 0924-2244.

Tumelero, N.; Ribeiro, J. \& Danilevicz, A. (2000). O QFD como ferramenta de priorização para o planejamento da qualidade. Proceedings of Brazilian Conference on Management of Product Development, São Carlos, Aug., 2000.

Vatthanakul, S.; Jangchud, A.; Jangchud, K.; Therdthai, N. \& Wilkinson, B. (2010). Gold kiwifruit leather product development using quality function deployment approach. Food Quality and Preference, Vol.21, No.3, 2010, pp. 339-345, ISSN 0950-3293.

Viaene, J. \& Januszewska, R. (1999). Quality function deployment in the chocolate industry. Food Quality \& Preference, Vol. 10, pp. 377-385. ISSN, 0950-3293.

Waisarayutt, C. \& Tutiyap, O. (2006). Application of Quality Function Deployment in Instant Rice Noodle Product Development. The Kasetsart Journal: Natural Sciences. Vol.40 (Suppl.) 162-171 p.

Westad, F.; Hersleth, M. \& Lea, P. (2004) Strategies for consumer segmentation with applications on preference data. Food Quality and Preference, Vol. 15, No. 7-8 , 2004, pp.681-687, ISSN 0950-3293.

Zarei, M.; Fakhrzad M. \& Paghaleh, M. J. (2011). Food supply chain leanness using a developed QFD model. Journal of Food Engineering, Vol. 102, pp. 25-33, ISSN 02608774 . 
SCIENTIFIC, HEALTH

AND SOCIAL ASPECTS

OF THE FOOD

INDUSTRY

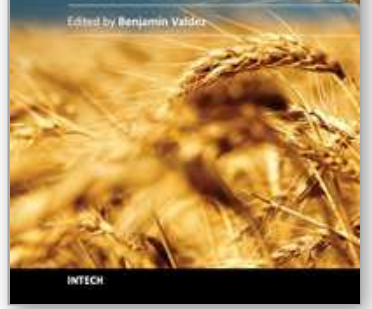

Scientific, Health and Social Aspects of the Food Industry

Edited by Dr. Benjamin Valdez

ISBN 978-953-307-916-5

Hard cover, 488 pages

Publisher InTech

Published online 01, February, 2012

Published in print edition February, 2012

This book presents the wisdom, knowledge and expertise of the food industry that ensures the supply of food to maintain the health, comfort, and wellbeing of humankind. The global food industry has the largest market: the world population of seven billion people. The book pioneers life-saving innovations and assists in the fight against world hunger and food shortages that threaten human essentials such as water and energy supply. Floods, droughts, fires, storms, climate change, global warming and greenhouse gas emissions can be devastating, altering the environment and, ultimately, the production of foods. Experts from industry and academia, as well as food producers, designers of food processing equipment, and corrosion practitioners have written special chapters for this rich compendium based on their encyclopedic knowledge and practical experience. This is a multi-authored book. The writers, who come from diverse areas of food science and technology, enrich this volume by presenting different approaches and orientations.

\section{How to reference}

In order to correctly reference this scholarly work, feel free to copy and paste the following:

Caroline Liboreiro Paiva and Ana Luisa Daibert Pinto (2012). Employment of the Quality Function Deployment (QFD) Method in the Development of Food Products, Scientific, Health and Social Aspects of the Food Industry, Dr. Benjamin Valdez (Ed.), ISBN: 978-953-307-916-5, InTech, Available from:

http://www.intechopen.com/books/scientific-health-and-social-aspects-of-the-food-industry/employment-of-thequality-function-deployment-qfd-method-in-the-development-of-food-products

\section{INTECH}

open science | open minds

\section{InTech Europe}

University Campus STeP Ri

Slavka Krautzeka 83/A

51000 Rijeka, Croatia

Phone: +385 (51) 770447

Fax: +385 (51) 686166

www.intechopen.com

\section{InTech China}

Unit 405, Office Block, Hotel Equatorial Shanghai

No.65, Yan An Road (West), Shanghai, 200040, China

中国上海市延安西路65号上海国际贵都大饭店办公楼405单元

Phone: +86-21-62489820

Fax: $+86-21-62489821$ 
(C) 2012 The Author(s). Licensee IntechOpen. This is an open access article distributed under the terms of the Creative Commons Attribution 3.0 License, which permits unrestricted use, distribution, and reproduction in any medium, provided the original work is properly cited. 